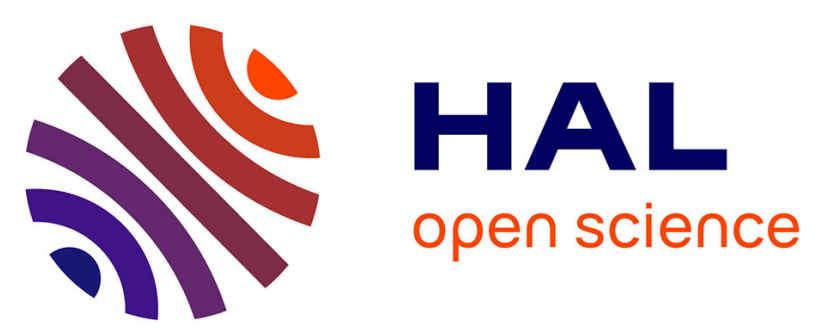

\title{
The Barley mlo-gene: an important powdery mildew resistance source
}

\author{
Michael Lyngkjær, Adrian Newton, Jannie Atzema, Susan Baker
}

\section{To cite this version:}

Michael Lyngkjær, Adrian Newton, Jannie Atzema, Susan Baker. The Barley mlo-gene: an important powdery mildew resistance source. Agronomie, 2000, 20 (7), pp.745-756. 10.1051/agro:2000173 . hal-00886078

\section{HAL Id: hal-00886078 https://hal.science/hal-00886078}

Submitted on 1 Jan 2000

HAL is a multi-disciplinary open access archive for the deposit and dissemination of scientific research documents, whether they are published or not. The documents may come from teaching and research institutions in France or abroad, or from public or private research centers.
L'archive ouverte pluridisciplinaire HAL, est destinée au dépôt et à la diffusion de documents scientifiques de niveau recherche, publiés ou non, émanant des établissements d'enseignement et de recherche français ou étrangers, des laboratoires publics ou privés. 


\title{
The Barley mlo-gene: an important powdery mildew resistance source
}

\author{
Michael F. LYNGKJÆR ${ }^{a *}$, Adrian C. Newton ${ }^{\mathrm{b}}$, Jannie L. AtZEMA ${ }^{\mathrm{c}}$, Susan J. BAKER ${ }^{\mathrm{d}}$ \\ a Plant Biology and Biogeochemistry Department, Ris $\emptyset$ National Laboratory, 4000 Roskilde, Denmark \\ ${ }^{\mathrm{b}}$ Scottish Crop Research Institute, Dundee DD2 5DA, Scotland, UK \\ ${ }^{c}$ Institute of Plant Science, Swiss Federal Institute of Technology, 8092 Zurich, Switzerland \\ ${ }^{\mathrm{d}}$ Department of Plant Science, University of Oxford, Oxford OX1 3RB, UK
}

(Received 16 May 2000; revised 12 July 2000; accepted 14 July 2000)

\begin{abstract}
This review briefly summarises recently generated knowledge about mlo powdery mildew resistance in barley. Barley mlo resistance has remained highly effective since commercial spring barley varieties with the resistance were first released in 1979. Currently, this resistance is the most used resistance in spring barley grown throughout Europe. Barley mlo resistance confers nearly total resistance against fungal penetration attempts. However, the efficiency of the resistance depends on several factors including epidermal cell type, host genetic background, environmental conditions and fungal genotype. Recently, the barley Mlo-gene has been cloned, but the exact function of the gene is not known. The Mlo-gene most likely regulates several mechanisms involved in penetration resistance against powdery mildew, and mlo mutations cause disfunction of the wild type Mlo-protein leading to increased resistance. The resistance mechanisms involved probably include earlier deposition and increased size of the host papilla response, callose deposition, production of phenolic compounds and cell wall strengthening by cross binding.
\end{abstract}

mlo resistance / powdery mildew / barley / resistance / virulence

Résumé - Le gène Mlo de l'orge : une importante source de résistance au mildiou. Cette revue résume les connaissances récemment acquises sur la résistance mlo à l'oïdium chez l'orge. Cette résistance est actuellement la plus utilisée dans les orges de printemps en Europe, et son efficacité s'est maintenue depuis son introduction en 1979 dans les variétés commerciales. La résistance mlo bloque la pénétration du champignon. Cependant, son expression dépend de plusieurs facteurs dont le type de cellules épidermiques, le fond génétique de l'hôte, les conditions climatiques et le génotype du champignon. Chez l'orge, le gène Mlo a récemment été cloné mais sa fonction précise n'est pas connue. Le gène Mlo régule vraisemblablement plusieurs mécanismes impliqués dans la résistance à la pénétration de l'oïdium, et les mutations mlo provoqueraient des dysfonctionnements de la protéine Mlo. Les mécanismes de résistance impliqués incluent probablement une déposition précoce et une taille supérieure de la papille émise par l'hôte, du dépôt de callose, de la production de composés phénoliques et du renforcement des parois cellulaires.

résistance mlo / oïdium / orge / résistance / virulence

Communicated by Rients E. Niks (Wageningen, The Netherlands)

* Correspondence and reprints

m.lyngkjaer@ risoe.dk 


\section{Introduction}

Powdery mildew is one of the most consistently damaging diseases of barley in Europe. It is caused by the obligate biotrophic fungus Blumeria graminis DC Speer f.sp. hordei Em. Marchal (Syn. Erysiphe graminis DC f.sp. hordei Em. Marchal). The fungus can infect all green plant parts causing premature tissue senescence leading to severe reductions in yield. Much effort is devoted to the exploitation of genetic plant resistance for disease control. However, most single genes for resistance in barley have proved ephemeral as virulent pathogen races capable of breaking down the resistance are rapidly selected in the agricultural situation. The recessive mlo-alleles of barley have proved to be an exception. Since commercial spring barley varieties with resistance based on mlo-alleles were first released in 1979, the resistance has remained highly effective. Currently, this powdery mildew resistance is the most used resistance in spring barley grown throughout Europe. Therefore, if the resistance should break down the consequences would be extremely serious.

The mlo powdery mildew resistance effectively prevents the mildew fungus from penetrating host epidermal cells, and thus prevents fungal haustorium formation and infection. This resistance is highly correlated with local papilla deposition in host epidermal cells beneath attempted fungal penetration sites. In susceptible barley lines with the dominant Mlo-allele, papillae are also produced, but these are not able to prevent fungal penetration with the same efficiency, so that the fungus is often able to infect, form haustoria and sporulate.

Work relating to the exploitation and characterisation of mlo powdery mildew resistance in barley has been reviewed several times, most recently by Jørgensen [30] and Schwarzbach [47]. The present article will summarise briefly knowledge concerning mlo powdery mildew resistance generated since then.

\section{The barley mlo-gene}

A major step towards understanding mlo powdery mildew resistance was taken when the barley
Mlo-gene was cloned and sequenced [12]. However, the wild-type Mlo-gene encodes a novel, plant-specific, integral membrane protein, the functions of which are still unknown $[12,44]$. The gene encodes a 533 amino acid protein that resides in the plasma membrane of leaf cells and is anchored by seven transmembrane helices so that the amino-terminus is extra-cellular and the carboxy-terminal tail is intra-cellular [12, 17, 44]. It has been suggested that the Mlo-protein is involved in regulation of one or more early cell defence responses and if this regulation is missing, i.e. in mlo mutants, the cell defence responses are activated earlier and/or more strongly than in susceptible barley [30, 51, 57]. Molecular analysis of eleven different induced mlo mutants confirmed the hypothesis that mlo resistance is caused by lack of function of the wild type Mlo-gene [12]. Further, the Mlo-protein seems to work in a cell autonomous way as transformation of epidermal cells in mlo resistant barley with the wild type Mlo-gene restored susceptibility of the transformed epidermal cells while surrounding cells retained their resistance [48].

Genome search in Arabdopsis thaliana has revealed the presence of approximately $35 \mathrm{Mlo}$ gene family members sharing a common gene structure [17, 44]. The Mlo family members show some similarities in topology and subcellular localisation, but not in sequence, to G-protein-coupled receptors in Caenorhabditis elegans and Homo sapiens [44]. These receptors are involved in mediating extracellular signals into amplified intracellular responses. The Mlo-protein may function in a similar way, but this remains to be confirmed [44].

The tendency of mlo containing barley to produce necrotic flecks, even under axenic conditions [57], seems to be a pleiotropic effect of the mloalleles. This suggests a possible involvement of the wild-type Mlo-gene in cell death control that functions independently of the mlo mediated penetration resistance response [12, 42, 44]. How this cell death relates to cell death involved in race specific hypersensitive resistance is not clear, but the data indicate the existence of at least two separate pathways leading to cell death in barley [42]. 


\section{Efficiency of mlo powdery mildew resistance}

The mlo resistance does not confer total resistance and the efficacy of the resistance may be modified by many factors including epidermal cell type, host genetic background, environmental conditions and fungal genotypes.

\subsection{Cell types}

In mlo resistant barley, long epidermal cells, located over vascular tissues, are normally not penetrated at all, while short cells are penetrated very rarely. Stomatal subsidiary cells, the very small epidermal cells directly adjacent to guard cells, are penetrated with a slightly greater frequency than short cells e.g. $[5,8,31]$. The phenomenon of enhanced subsidiary cell susceptibility to powdery mildew infection in cereals is well established e.g. [24] although the reasons for this are not fully explained. Skou [50] suggested that subsidiary cells adjacent to stomata were unable to form papillae because of their unique physiology and the flexibility of their walls that relates to stomatal movement. Infections in this type of cell are normally responsible for the characteristic occurrence of occasional powdery mildew colonies seen on mlo resistant barley leaves.

\subsection{The host}

The general host genetic background may strongly affect the efficiency of mlo resistance, which may vary in terms of the number of colonies formed from near zero to close to compatibility [6, 29, 31]. Through mutation studies, two genes, Rorl and Ror2, which may be responsible for this variation, have been identified as required for full expression of mlo resistance [19]. If an mlo-allele is present together with a mutated ror 1 or ror 2 gene, the mlo resistance is compromised and the host becomes susceptible to powdery mildew attack. Different mlo-alleles have also been reported to confer differences in the quantitative expression of resistance [22, 45]. However, this could not be confirmed in a microscope examination of 11 different induced mlo-alleles back crossed to $\mathrm{Cv}$. Ingrid [6]. Here, no significant differences were found in the overall percentage of successful penetration (Fig. 1), suggesting that the host genetic background in which the mlo-gene is placed, and not the actual mlo-allele, determines the efficiency of mlo resistance in barley.

\subsection{Environmental factors}

In the field, mlo resistant barley cultivars occasionally suffer from outbreaks of powdery mildew. These outbreaks are sporadic and transient, and do not appear to be due to genetic changes in the powdery mildew population (see later), but appear

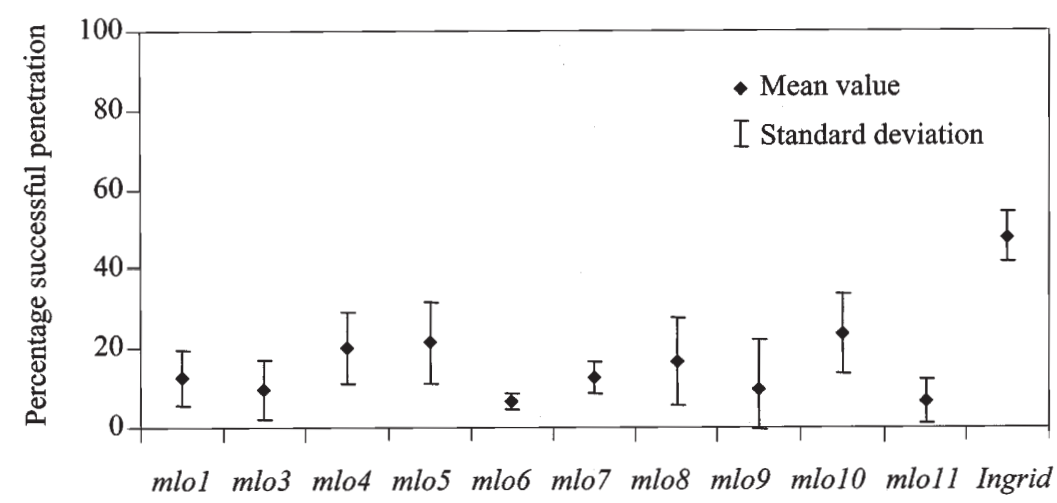

Figure 1. Effects of different resistance alleles on the efficiency of mlo-resistance in barley. Percentage successful powdery mildew penetration (haustorium formation) in Ingrid near isogenic barley lines with different $m l o$-alleles, 48 hours after inoculation. From J. Atzema [6]. 
Table I. Effect of water stress release on mlo resistance in the barley cv. Atem. Modified from Newton and Young [40].

\begin{tabular}{lcc}
\hline & \multicolumn{2}{c}{$\begin{array}{c}\text { Numbers of powdery mildew colonies } \\
\text { per leaf }\end{array}$} \\
\cline { 2 - 3 } $\begin{array}{l}\text { Water stress } \\
\text { treatment }\end{array}$ & $\begin{array}{c}\text { First formed } \\
\text { leaf }\end{array}$ & $\begin{array}{c}\text { Second formed } \\
\text { leaf }\end{array}$ \\
\hline No stress & 0.00 & 0.00 \\
Mild stress & 0.64 & 0.75 \\
High stress & 12.75 & 0.25 \\
& \multicolumn{2}{c}{ LSD $=2.44$} \\
\hline
\end{tabular}

related to unusual environmental conditions [30]. Experimentally it was shown that relief from water stress in barley cultivars might result in temporary partial breakdown of mlo resistance both under controlled greenhouse conditions and in field experiments $[7,8,40]$ (Tab. I). Relief from water stress increased susceptibility of both Mlo susceptible and mlo resistant barley for a short period of time, with maximum mildew infection frequency being attained when the water stress was relieved approximately seven hours after powdery mildew inoculation [8]. The extent of resistance breakdown also depended on the genetic background of the barley in which the mlo-gene was contained, and not the actual mlo mutant used [8]. Some barley genotypes do not suffer from breakdown after relief of water stress and QTL mapping has demonstrated that at least one locus independent of the $m l o$ gene is responsible for this characteristic (Newton, unpublished data). Similar, partial breakdown of mlo resistance has been obtained when barley recovers from cold stress [Lyngkjær and Carver unpublished] (Tab. II).

Availability of nutrients may influence the susceptibility of barley to powdery mildew. High nitrogen levels are known to cause a general increase in susceptibility [27] and nitrogen status was also found to increase the level of infection following relief from water stress in mlo resistant barley $[7,40]$. However, deprivation of silicon, that normally leads to increased powdery mildew susceptibility [58], did not affect the efficiency of $m l o$ resistance, although the size of papillae produced
Table II. Effect of cold stress relief on mlo resistance in first formed (seedling leaves) of the Ris $\varnothing$ 5678R barley line. Plants were grown at 16 or $20{ }^{\circ} \mathrm{C}$. Stress was applied by lowering the temperature to 4 or $8{ }^{\circ} \mathrm{C}$ for 48 hours. Plants were inoculated at the end of the cold period, incubated at the original, higher temperature, and numbers of colonies were counted 7 days later [Lyngkjær and Carver, unpublished].

\begin{tabular}{lccc}
\hline & \multicolumn{3}{c}{$\begin{array}{c}\text { Numbers of powdery mildew colonies } \\
\text { per leaf }\end{array}$} \\
\cline { 2 - 4 } $\begin{array}{l}\text { Growth } \\
\text { temperature }\end{array}$ & No stress & $\begin{array}{c}48 \text { hours } \\
\text { at } 4{ }^{\circ} \mathrm{C}\end{array}$ & $\begin{array}{c}48 \text { hours } \\
\text { at } 8{ }^{\circ} \mathrm{C}\end{array}$ \\
\hline $16{ }^{\circ} \mathrm{C}$ & & 3.3 & 4.4 \\
$20{ }^{\circ} \mathrm{C}$ & 1.2 & 1.2 & 4.9 \\
\hline
\end{tabular}
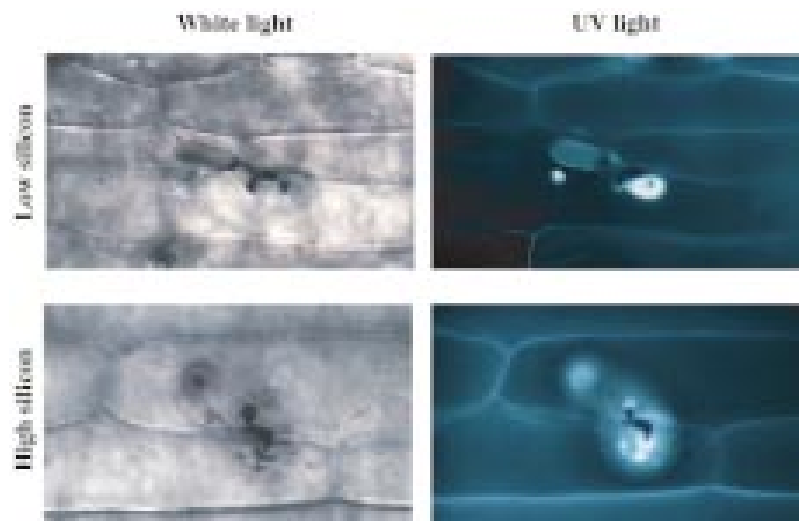

Figure 2. Effects of low and high silicon ( $\mathrm{Si}$ ) levels on papilla formation in the mlo resistant barley line Ris $\varnothing$ 5678R attacked by powdery mildew. Staining with leuco aniline blue and UV light microscopy was used to detect the presence of callose. High Si content is associated with abundant callose while deprivation of $\mathrm{Si}$ greatly reduced the abundance of callose ([60], Lyngkjær and Carver, unpublished).

in response to attack was changed dramatically ([60], Lyngkjær and Carver unpublished] (Fig. 2).

\subsection{The fungus}

Over the past 25 years, barley cultivars carrying mlo resistance have become widely used in Europe. By 1988 they occupied about 25 percent of the total area devoted to spring barley [4], and by 
1993-94 about 70 percent of the spring barley area in the UK and Germany contained mlo [40, 47]. Despite this very intensive use, mlo resistance has remained highly effective against powdery mildew populations in the field. In an evaluation of data from the European Barley Disease Nursery from 1976-1988, no indication of increase in disease severity was found on mlo resistant cultivars in Europe [4] and this situation remains unchanged.

In Denmark, screening for mlo-virulence in isolates collected on mlo resistant seedlings from 1992 to 1995 showed no increased virulence [Hovmøller and Lyngkjær unpublished data]. Similar results were obtained from isolates collected in Germany during 1993 and 1994 [6]. However, in the UK Cereal Pathogen Virulence Survey in 1998, the spring barley Riviera, an mlo variety, showed noticeable levels of mildew, and pustule transfer experiments in Northern Ireland suggested a shift, albeit small, in virulence for $m l o$ [52]. (See also the paper by Hovmøller et al., in this volume).

It would not be surprising if there is an eventual shift towards increased mlo-virulence in field populations of powdery mildew. Two powdery mildew isolates with the potential to overcome, at least partially, mlo resistance have been described [36, 46]. Both powdery mildew isolates show improved penetration efficiency and are able to infect all epidermal cell types on mlo resistant barley. The first, isolate HL3/5 (originally called HL-3 [46]), was selected for the increased number of colonies formed during recurrent propagation on an mlo resistant barley line, over 37 successive conidial generations in the laboratory [46]. The other, powdery mildew isolate, Race I, was originally collected from field crops in Japan in the 1950s. This was before any commercial growth of mlo resistant cultivars, and only recently its mlo-virulence was discovered [36]. In tests on near isogenic barley lines with and without mlo resistance, isolate HL3/5 normally develops about 10 to 60 per cent of the colonies it produces on the susceptible barley line. This is between 50 to 2000 times more colonies than its progenitor powdery mildew isolate GE3 e.g. [5, 35, 46] (Fig. 3). Race I was found to be at least as virulent, and possibly more so, than HL3/5 [36].

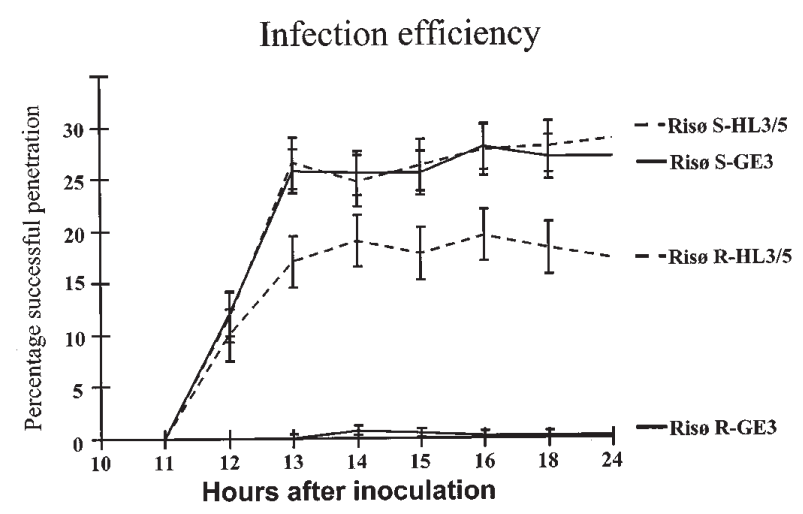

Figure 3. Time-course showing successful penetration (haustorium formation) by the mlo virulent HL3/5 and the mlo avirulent GE3 powdery mildew isolates on leaves of the two near isogenic barley lines Ris $\varnothing 5678 \mathrm{R}$ (with mlo5 resistance) and Ris $\varnothing$ 5678S (susceptible), at 10 to 24 hours after inoculation. Error bars represent $95 \%$ confidence intervals. From Lyngkjær and Østergård [35].

The genetic basis of mlo-virulence in the haploid barley powdery mildew fungus is not well characterised. Schwarzbach [46] noted that the slow increase in fitness during his selection experiment suggested that mlo-virulence was controlled by more than one locus. Furthermore, he suggested that at least three genes are involved, because the performance (i.e. the proportion of conidia that formed secondary elongating hyphae) among 6 genotypes sampled at the end of the selection experiment could be grouped into four classes. Based on several crosses between the mlo virulent powdery mildew isolate HL3/5 and avirulent field isolates, and later a series of backcrosses, two hypotheses for the genetic basis of mlo-virulence were suggested [6]: (1) that mlo-virulence depends on the expression of one major virulence gene and two minor additive genes with a fourth gene that can partly inhibit the major gene. (2) that mlo-virulence depends on the expression of one major virulence gene and two minor additive genes, and one more additive minor gene with smaller effect.

The indication that at least three genes were involved and the relatively low infection efficiency of these isolates capable of growing on resistant lines, led Jørgensen [28] to suggest that these powdery mildew isolates should be called 'aggressive' and not 'virulent'. However, experimentation using 
the selected mlo-virulent isolate, HL3/5, and its progenitor isolate, GE3, showed that mlo-virulence is not a general increase in pathogen aggressiveness since mlo virulent and avirulent isolates have the same fitness on susceptible barley lines [35] (Fig. 3). Because of this and the indication of specificity of the interaction, powdery mildew isolates with increased infection efficiency on mlo resistant barley should be termed mlo virulent. However, this virulence is quantitative and may not be directly comparable to virulence shown by isolates capable of overcoming other, race specific, major genes for powdery mildew resistance.

\subsection{Interaction with other powdery mildew resistance genes and influence on other diseases}

The mlo resistance works independently from other powdery mildew resistance genes in barley and can be combined with these to produce powdery mildew 'multi-resistant' barley plants. However, the mlo gene seems to confer no resistance to diseases other than barley powdery mildew [30], and it was suggested that mlo resistance may affect only pathogens that infect living epidermal cells. Thus, it is not effective against biotrophic fungal pathogens such as leaf rust (Puccinia hordei) which enter through open stomata and infect mesophyll cells, or against necrotrophic fungal pathogens, such as net blotch (Drechslera teres), which exude toxins and kill the host tissue during infection [30]. However, recently it has been demonstrated that the presence of various mlo alleles confer enhanced susceptibility to rice blast (Magnaporthe grisea) whereas, by contrast, the wild type Mlo-gene confers resistance [26]. This shows that the mlo gene does not inevitably confer resistance against fungal pathogens that penetrate epidermal cells, and indicates that the Mlo-gene may play a complex role during infection of barley by different pathogens [26]. Increased susceptibility to rice blast of mlo barley may cause problems in some areas of the world such as northern Italy, southern France or Asia [26] where M. grisea is endemic. It has also been suggested that mlo barley is more susceptible to Rhynchosporium secalis. However, analysis of crosses between barley cultivars demonstrated that this was not attributable to the mlo gene itself but, rather, to the genetic background, and is most likely a consequence of low priority being given to $R$. secalis resistance in breeding programmes ([11], W.T.B. Thomas, Scottish Crap Research Institute, unpublished).

A.

B

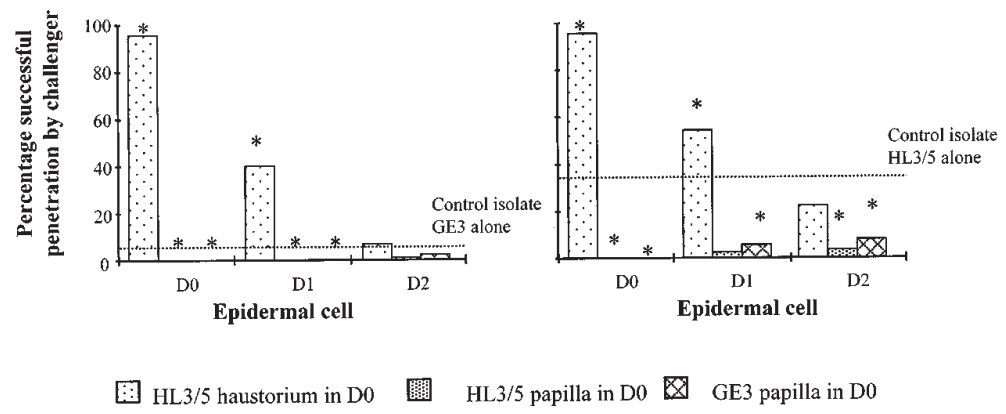

Figure 4. Percentage of challenger attacks by appressoria of the mlo avirulent powdery mildew isolate GE3 (A) or the $m l o$ virulent isolate HL3/5 (B) associated with successful penetration (haustorium formation) on the mlo5 resistant Ris $\varnothing$ 5678R barley line when earlier inducer attack by isolate HL3/5 had successfully penetrated and a haustorium remained in the attacked D0 cell, or had failed to penetrate and a papilla remained in the attacked D0 cell or, similarly, inducer attack by isolate GE3 had failed and a papilla remained in the attacked D0 cell. Data are given for penetration success into D0 cells (those directly attacked by the inducer), D1 cells (immediately adjacent to D0), and D2 cells (separated from the D0 by a D1 cell). * above a column indicates that the $95 \%$ confidence interval around the fitted mean differed significantly from the equivalent $95 \%$ confidence interval around the control. Modified from Lyngkjær and Carver [34]. 


\subsection{Induced susceptibility and resistance}

The powdery mildew fungus may by itself change the efficiency of mlo powdery mildew resistance by inducing localised changes in susceptibility of cells to attack by modifying their 'accessibility' (effectively increasing susceptibility) or 'inaccessibility' (effectively increasing resistance) e.g. [34, 41]. The cellular mechanisms behind induced (in)accessibility have been studied in mlo resistant barley with both mlo virulent and avirulent powdery mildew [34]. This showed that if attack on an mlo barley by a virulent isolate is successful and a haustorium is formed, mlo resistance is nearly totally suppressed rendering infected cells, and to some extent their immediate neighbours, highly accessible (susceptible) to later attack by both mlo virulent and avirulent powdery mildew isolates. By contrast, if the first mildew attack fails, cells are rendered highly inaccessible (resistant) to later attack by both virulent and avirulent powdery mildew isolates [34] (Fig. 4). This means that as long as most individuals in a powdery mildew population are unable to infect mlo resistant barley successfully, the plant will express a very high level of induced resistance in the field, including against mlo virulent powdery mildew isolates. On the other hand if mlo virulence should be common, induced susceptibility may contribute to increased disease severity on mlo resistant barley.

\section{Resistance mechanisms}

It has been suggested that many disease resistance mechanisms may be affected/regulated by the wild type Mlo-gene and thereby involved in the penetration resistance conferred by mlo-alleles in barley. These mechanisms are all related to apposition/papilla formation and cell wall modifications, and include effects on the timing and size of the host papilla response, callose deposition, production of phenolic compounds and cell wall strengthening by cross linking.

\subsection{Timing and size of host response}

Rapid papilla formation in mlo resistant barley has been suggested as one mechanism involved in resistance [10, 21, 51]. Skou et al. [51] showed a significant difference in initiation of appositions (haloes and papillae) between a resistant and a near isogenic susceptible barley line, and concluded that the early formation of papilla was responsible for mlo resistance. Alterations in papilla deposition have also been shown in mlo resistant barley coleoptiles where papillae were initiated 60 minutes before attempted penetration by the fungus, in contrast to susceptible coleoptiles where they were initiated 40 minutes after attempted penetration [21]. The importance of timing of papilla deposition in relation to attempted penetration has also been supported by inhibitor studies, in which a delay in papillae formation in treated coleoptiles of an $m l o$ resistant barley line was observed coincidentally with an increase in fungal infection $[10,21]$.

Increased papilla size and frequency at attempted penetration sites also correlates with mlo resistance $[21,49,51,53,58]$. The diameters of papillae have been measured as almost two times larger in resistant lines compared to susceptible lines at the time of fungal penetration e.g. [35]. However, some susceptible barley lines, i.e. Kobinkatagi, also produced large papillae implying that it is not only the final papilla size that determines efficacy of resistance [51]. Papillae are also formed more frequently during the early stages of attempted penetration in mlo resistant barley than in susceptible barley lines although eventual papilla frequency is equal between the two lines [35, 53, 58]. Despite these findings, some evidence suggests that papilla formation is not necessary for mlo resistance. Thus, low speed-centrifugation inhibited papilla formation without causing any increase in successful penetration [54].

\subsection{Callose}

The deposition rate of callose and the final amount of callose in papillae have also been regarded as important to the effectiveness of papillae in mlo resistant barley [2, 10, 21, 35, 49, 54]. Callose is synthesised by the plasma membrane bound $1,3-\beta$-glucan synthase $[32,39]$. No differences were observed in specific activity of callose synthase between mlo resistant barley and susceptible 
barley [43], suggesting that regulation of the enzyme must be important in controlling the formation of the large callose containing papillae associated with mlo resistance. Calcium $\left(\mathrm{Ca}^{2+}\right)$ strongly increases the activity of callose synthase [33], and fungal penetration attempts may induce an influx of $\mathrm{Ca}^{2+}$ to the cytosol activating the enzyme. When treated with $\mathrm{Ca}^{2+}$ chelators mlo resistant barley became susceptible [9], and lack of the wild-type Mlo-protein may thus allow for an early and rapid elevation of the $\mathrm{Ca}^{2+}$ level in the host cell $[1,9]$.

Bayles et al. [10] provided further experimental evidence supporting the importance of callose for papilla formation. They showed that treatment with the glucose analogue, 2-deoxy-D-glucose (DDG), increased the susceptibility of mlo resistant barley. The glucose analogue DDG is described as a powerful inhibitor of callose formation in vivo [25] but it does not inhibit activity of the callose synthase enzyme in vitro $[37,39]$. However, the effects of DDG, and another glucose analogue mannose [37], may well be indirect since both are known to sequester plant cell phosphate [18, 20, 38]. Phosphate sequestration would reduce the plant cells potential to synthesise the ATP needed for vital phosphorylation reactions during energy metabolism [23, 56]. This would presumably result in lower energy being available for penetration resistance and lead to increased susceptibility.

\subsection{Phenolics}

Papillae formed in both resistant and susceptible barley often contain autofluorogenic compounds thought to be phenolics $[15,16,59]$. Phenolics are synthesised de novo in response to powdery mildew attack [16] and are involved in penetration resistance, possibly through strengthening epidermal cell walls and papillae by cross-linking cell wall materials [13, 16, 59]. Compaction of papillae due to phenolic cross-linking, which makes papillae and cell walls resistant to digestion with cellulase, happens at least two hours earlier in mlo resistant barley than in susceptible barley [55]. Compacted papillae and cell wall regions where cellulose fibres are bound to phenolics are likely to impede penetration by the fungus. The timing and

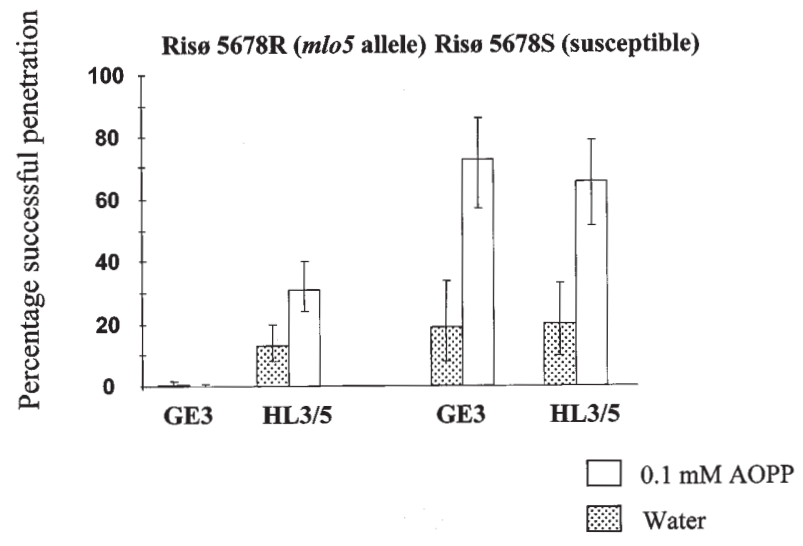

Figure 5. Involvement of phenolic compounds in barley mloresistance. Mean percentages of appressoria of the powdery mildew isolates GE3 (mlo avirulent) and HL3/5 (mlo virulent) successfully penetrating (forming haustorium) in leaf epidermal cells of barley isolines Risø 5678R (mlo5 resistant) and Ris $\varnothing 5678 \mathrm{~S}$ (susceptible) treated with water (controls) or with $0.1 \mathrm{mM}$ AOPP. Means are based on observation of 100 appressoria on each of three leaves subjected to each treatment. Error bars represent $95 \%$ confidence intervals. Modified from Lyngkjær et al. [36].

rapidity of this compaction may be important for the efficiency of mlo resistance.

Phenylalanine ammonia lyase (PAL), the enzyme which catalyses the first committed step in phenolic compound synthesis, can be inhibited by treating leaves with $\alpha$-aminooxy- $\beta$-phenylpropionic acid (AOPP) [3]. Treatment of susceptible barley with AOPP, lead to a marked decrease in papillae autofluorescence and to substantially increased susceptibility [14]. This indicates that in barley, phenolic compounds present in papillae contribute greatly to inherent resistance and to the potential effectiveness of papillae. A soluble phenolic polyamine compound, with fungistatic or anti-fungal properties, has been shown to accumulate differentially in papillae in mlo resistant and susceptible barley suggesting that this compound plays an important role in mlo resistance [55]. However, when mlo barley was treated with AOPP, resistance was maintained despite a reduction in papilla autofluorescence [59]. This suggests that components other than phenolic compounds are largely responsible for the resistance of papillae in mlo barley. Nevertheless, tests with mlo virulent 
powdery mildew have shown that AOPP treatment of mlo barley resulted in increased susceptibility to mlo virulent powdery mildew (Fig. 5) [37]. This indicates that while phenolics are not the primary cause of resistance in mlo barley, they act as a backup defence that contributes to limiting penetration where the primary defence fails.

\section{Concluding remarks}

The apparently complex function of mlo resistance seems to make it difficult for the powdery mildew fungus to develop virulence. This may be because the fungus has to deal with many changed and increased host responses involved in papilla formation and cell wall alterations. This is probably also why several genes are involved in generating mlo-virulence. However, the demonstration that the Japanese field isolate is virulent to mlo barley [35], supports Schwarzbach's [46] observation that powdery mildew has the genetic potential to overcome, at least partially, mlo resistance in the field. If, as seems inevitable, mlo cultivars remain widely used, selection pressure will probably lead eventually to the evolution of mlo-virulence. Encouragingly, however, although some survey results indicate a small increase in mlo-virulence, no evidence yet indicates that widespread breakdown of the resistance is imminent. The fact that failed fungal penetration attempts strongly induce local resistance may help to preserve and prolong the durability of mlo. In order to maintain the effectiveness of mlo resistance it is desirable that selection pressure should not be increased by further increase in the area of mlo-based spring barley. Similarly, the gene should not be introduced to winter barley varieties, which would provide a green bridge selective for virulent isolates. Additionally, combining mlo resistance with new race-specific, single genes for powdery mildew resistances should delay selection of mlo virulence by demanding the evolution of novel, complex virulence combinations before biotrophy can become established.

Acknowledgements: The authors wish to thank COST Action 817 for supporting travel expenses that were necessary for meeting and to carry out short-term scientific missions.

\section{References}

[1] Aist J.R., Gold R.E., Prevention of fungal ingress: The role of papillae and calcium, in: Nishimura S., Vance C.P., Doke N. (Eds.), Molecular Determinants of Plant Diseases, Springer-Verlag, Berlin, 1987, pp. 47-58.

[2] Aist J.R., Randall E.G., Bayles C.J., Morrison G.H., Chandra S., Israel H.W., Evidence that molecular components of papillae may be involved in mlo resistance to barley powdery mildew, Physiol. Mol. Plant Pathol. 33 (1988) 17-32.

[3] Amrhein N., Godeke K.H., $\alpha$-Aminooxy- $\beta$ phenylpropionic acid a potent inhibitor of L-phenylalanine ammonia-lyase in vitro and in vivo, Plant Sci. Lett. 8 (1977) 313-317.

[4] Andersen L., Mlo aggressiveness in European barley powdery mildew, in: Jørgensen J.H. (Ed.), Integrated Control of Cereal Mildews: Virulence Patterns and Their Change. Ris $\varnothing$ National Laboratory, Roskilde, Denmark, 1991, pp. 187-195.

[5] Andersen L., Jørgensen J.H., Mlo aggressiveness of barley powdery mildew, Norw. J. Agric. Sci. 7 (1992) 77-87.

[6] Atzema J.L., Durability of mlo resistance in barley against powdery mildew caused by Erysiphe graminis f.sp. hordei, Ph.D. thesis, Diss. ETH: No. 12782, Institute of Plant Science, Swiss Federal Institute of Technology, Zurich, 1998.

[7] Baker S.J., Newton A.C., Crabb D., Guy D.C., Jefferies R.A., Mackerron D.K.L., Thomas W.T.B., Gurr S.J., Temporary partial breakdown of mlo-resistance in spring barley by sudden relief of soil waterstress under field conditions: The effects of genetic background and mlo allele, Plant Pathol. 47 (1998) 401-410.

[8] Baker S.J., Newton A.C., Gurr S.J., Cellular characteristics of temporary partial breakdown of mlo-resistance in barley to powdery mildew, Physiol. Mol. Plant Pathol. 56 (2000) 1-11.

[9] Bayles C.J., Aist J.R., Apparent calcium mediation of resistance of mlo barley mutant to powdery mildew, Physiol. Mol. Plant Pathol. 30 (1987) 337-345.

[10] Bayles C.J., Ghemawat M.S., Aist J.R., Inhibition by 2-deoxy-D-glucose of callose formation, 
papilla deposition, and resistance to powdery mildew in an mlo barley mutant, Physiol. Mol. Plant Pathol. 36 (1990) 63-72.

[11] Brown J.K.M., Jones E.R.L., The effect of the mlo mildew resistance gene on Rhynchosporium secalis of barley, UK Cereal Pathogen Virulence Survey 1995, Annual Report, 1996, pp. 47-49.

[12] Büschges R., Hollricher K., Panstruga R., Simons G., Wolter M., Frijters A., van Daelen R., van der Lee T., Diergaarde P., Groenendijk J., Topsch S., Vos P., Salamini F., Schulze-Lefert P., The barley mlo gene: A novel control element of plant pathogen resistance, Cell 88 (1997) 695-705.

[13] Carver T.L.W., Robbins M.P., Zeyen R.J., Effects of two PAL inhibitors on the susceptibility and localized autofluorescent host cell responses of oat leaves attacked by Erysiphe graminis DC, Physiol. Mol. Plant Pathol. 39 (1991) 269-287.

[14] Carver T.L.W., Zeyen R.J., Robbins M.P., Dearne G.A., Effects of the PAL inhibitor, AOPP, on oat, barley and wheat cell responses to appropriate and inappropriate formae speciales of E. graminis DC, Physiol. Mol. Plant Pathol. 41 (1992) 397-409.

[15] Carver T.L.W., Zeyen R.J., Bushnell W.R., Inhibition of phenylalanine ammonia lyase and cinnamyl alcohol dehydrogenase increases quantitative susceptibility of barley to powdery mildew (Erysiphe graminis DC), Physiol. Mol. Plant Pathol. 44 (1994) 261-272.

[16] Clark T.A., Zeyen R.J., Smith A.G., Carver T.L.W., Vance C.P., Phenylalanine ammonia lyase mRNA accumulation, enzyme activity and cytoplasmic responses in barley isolines, differing at $\mathrm{Ml}-\mathrm{a}$ and $\mathrm{Ml}-\mathrm{o}$ loci, attacked by Erysiphe graminis f. sp. hordei, Physiol. Mol. Plant Pathol. 44 (1994) 171-185.

[17] Devoto A., Piffanelli P., Nilsson I., Wallin E., Panstruga R., von Heijne G., Schulze-Lefert P., Topology, subcellular localization, and sequence diversity of the Mlo family in plants, J. Biol. Chem. 274 (1999) 34993-35004.

[18] Egyud L.G., Whelan W.J., The substrate specificities of phosphoglucomutase and phosphoglucose isomerase, Biochem. J. 86 (1963) 11-12.

[19] Freialdenhoven A., Peterhänsel P., Kurth J., Kreuzaler F., Schulze-Lefert P., Identification of genes required for the function of non-race-specific mlo resistance to powdery mildew in barley, Plant Cell 8 (1996) $5-14$.

[20] Ghaouth A.E., Wilson C.L., Wisniewski M.E., Sugar analogs as potential fungicides for postharvest pathogens of apple and peach, Plant Dis. 79 (1995) 54-258.

[21] Gold R.E., Aist J.R., Hazen B.E., Stolzenburg M.C., Marshall M.R., Israel H.W., Effects of calcium nitrate and chlortetracycline on papilla formation, mlo resistance and susceptibility of barley to powdery mildew, Physiol. Mol. Plant Pathol. 29 (1986) 115-129.

[22] Hentrich W., Habekuss A., Untersuchungen an heteroallelen mehltauresistenten mutanten des mlo locus der sommergerste, Vortr. Pflanzenz. 19 (1991) 311-312.

[23] Herold A., Lewis D.H., Mannose and green plants: occurrence, physiology and metabolism, and use as a tool to study the role of orthophosphate, New Phytol. 79 (1977) 1-40.

[24] Hirata K., Notes on haustoria, hyphae and conidia of the powdery mildew fungus of barley Erysiphe graminis f. sp. hordei, Memoirs of the Faculty of Agriculture, Niigata University 6, 1967, pp. 207-259.

[25] Jaffe M.J., Leopold A.C., Callose deposition during gravitropism of Zea mays and Pisum sativum and its inhibition by 2-deoxy-D-glucose, Planta 161 (1984) $20-26$.

[26] Jarosch B., Kogel K.H., Schaffrath U., The ambivalence of the barley Mlo locus: Mutations conferring resistance against powdery mildew (Blumeria graminis f. sp. hordei) enhance susceptibility to the rice blast fungus Magnaporthe grisea, Molec. Plant-Microbe Inter. 12 (1999) 508-514.

[27] Jensen B., Munk L., Nitrogen-induced changes in colony density and spore production of Erysiphe graminis f. sp. hordei on seedlings of six spring barley cultivars, Plant Pathol. 46 (1997) 191-202.

[28] Jørgensen J.H., Experience and conclusions from the work at Ris $\varnothing$ on induced mutations for powdery mildew resistance in barley, in: Anonymous (Ed.), Induced mutations for disease resistance in crop plants II. International Atomic Energy Agency, Vienna, 1983, pp. 3-86.

[29] Jørgensen J.H., Mechanism of Mlo resistance to barley powdery mildew, Sver. Utsädför. Tidsskr. 2 (1991) 80-84.

[30] Jørgensen J.H., Discovery, characterization and exploitation of Mlo powdery mildew resistance in barley, Euphytica 63 (1992) 141-152.

[31] Jørgensen J.H., Mortensen K., Primary infection by Erysiphe graminis f. sp. hordei of barley mutants with resistance genes in the mlo locus, Phytopathology 67 (1977) 678-685. 
[32] Kauss H., Some aspects of calcium dependent regulation in plant metabolism, Annu. Rev. Plant Physiol. 38 (1987) 47-72.

[33] Kauss H., Köhle H., Jeblick W., Proteolytic activation and stimulation by $\mathrm{Ca}^{2+}$ of glucan synthase from soybean cells, FEBS Lett. 158 (1983) 84-88.

[34] Lyngkjær M.F., Carver T.L.W., Modification of mlo5 resistance to Blumeria graminis attack in barley as a consequence of induced accessibility and inaccessibility, Physiol. Mol. Plant Pathol. 55 (1999) 163-174.

[35] Lyngkjær M.F., Østergård H., Interaction between powdery mildew and barley with mlo5 mildew resistance, Plant Pathol. 47 (1998) 252-258.

[36] Lyngkjær M.F., Jensen H.P., Østergård H., A Japanese powdery mildew isolate with exceptionally large infection efficiency on Mlo-resistant barley, Plant Pathol. 44 (1995) 786-790.

[37] Lyngkjær M.F., Carver T.L.W., Zeyen R.J., Suppression of resistance to Erysiphe graminis f. sp. hordei conferred by the mlo5 barley powdery mildew resistance gene, Physiol. Mol. Plant Pathol. 50 (1997) 17-36.

[38] Moore D., Effects of hexose analogues on fungi: mechanisms of inhibition and of resistance, New Phytol. 87 (1981) 487-515.

[39] Morrow D.L., Lucas W.J., (1-3)- $\beta$-D-glucan synthase from sugar beet. II. Product inhibition by UDP, Plant Physiol. 84 (1987) 565-567.

[40] Newton A.C., Young I.M., Temporary partial breakdown of Mlo-resistance in spring barley by the sudden relief of soil water stress, Plant Pathol. 45 (1996) 973-977.

[41] Ouchi S., Oku H., Hibino C., Localization of induced resistance and susceptibility in barley leaves inoculated with the powdery mildew fungus, Phytopathology 66 (1976) 901-905.

[42] Pedersen L.H., 1,3-ß-glucansynthase activity and callose synthesis in barley mlo mutants and mother varieties, Plant Physiol. 79 (1990) 02 (Abstract).

[43] Peterhänsel C., Freialdenhoven A., Kurth J., Kolsch R., Schulze-Lefert P., Interaction analyses of genes required for resistance responses to powdery mildew in barley reveal distinct pathways leading to leaf cell death, Plant Cell 9 (1997) 1397-1409.

[44] Piffanelli P., Devoto A., Schulze-Lefert P., Defence signalling pathways in cereals, Curr. Opin. Plant Biol. 2 (1999) 295-300.

[45] Röbbelen G., Heun M., Genetic analysis of partial resistance against powdery mildew in induced mutants of barley, in: Anonymous (Ed.), Plant Mutation Breeding for Crop Improvement, International Atomic Energy Agency, Vienna, 1991, pp. 93-111.

[46] Schwarzbach E., Response to selection for virulence against the mlo based mildew resistance in barley, not fitting the gene-for-gene hypothesis, Barley Genet. Newslett. 9 (1979) 85-88.

[47] Schwarzbach E., The mlo based resistance of barley to mildew and the response of mildew populations to the use of varieties with the mlo gene, Czech J. Genet. Plant Breed. 34 (1998) 3-10.

[48] Shirasu K., Nielsen K., Piffanelli P., Oliver R., Schulze-Lefert P., Cell-autonomous complementation of mlo resistance using a biolistic transient expression system, Plant J. 17 (1999) 293-299.

[49] Skou J.P., Callose formation responsible for the powdery mildew resistance in barley with genes in the mlo locus, Phytopathol. Z. 104 (1982) 90-95.

[50] Skou J.P., On the enhanced callose deposition in barley with mlo powdery mildew resistance genes, Phytopathol. Z. 112 (1985) 207-216.

[51] Skou J.P., Jørgensen J.H., Lilholt U., Comparative studies on callose formation in powdery mildew compatible and incompatible barley, Phytopathol. Z. 109 (1984) 147-168.

[52] Slater S.E., Clarkson J.D.S., Mildew of barley, U.K. Cereal Pathogen Virulence Survey 1998, Annual Report, 1999, pp. 43-51.

[53] Stolzenburg M.C., Aist J.R., Israel H.W., The role of papilla in resistance to powdery mildew conditioned by the mlo gene in barley. I. Correlative evidence, Physiol. Plant Pathol. 25 (1984) 337-346.

[54] Stolzenburg M.C., Aist J.R., Israel H.W., The role of papilla in resistance to powdery mildew conditioned by the mlo gene in barley. II. Experimental evidence, Physiol. Plant Pathol. 25 (1984) 347-361.

[55] von Ropenack E., Parr A., Schulze-Lefert P., Structural analyses and dynamics of soluble and cell wall-bound phenolics in a broad spectrum resistance to the powdery mildew fungus in barley, J. Biol. Chem. 273 (1998) 9013-9022.

[56] Watkins C.B., Frenkel C., Inhibition of pear fruit ripening by mannose, Plant Physiol. 85 (1987) 56-61.

[57] Wolter M., Hollricher K., Salamini F., SchulzeLefert P., The mlo resistance alleles to powdery mildew infection in barley trigger a developmentally controlled defense mimic phenotype, Mol. Gen. Genet. 239 (1993) 122-128. 
[58] Zeyen R.J., Ahlstrand G.G., Carver T.L.W., Xray microanalysis of frozen-hydrated, freeze-dried, and critical point dried leaf specimens - Determination of soluble and insoluble chemical elements at Erysiphe graminis epidermal cell papilla sites in barley isolines containing mlo and mlo alleles, Can. J. Bot. 71 (1993) 284-296.

[59] Zeyen R.J., Bushnell W.R., Carver T.L.W., Robbins M.P., Clark T.A., Boyles D.A., Vance C.P.,
Inhibiting phenylalanine ammonia lyase and cinnamylalcohol dehydrogenase suppresses Mlal (HR) but not mlo5 (non-HR) barley powdery mildew resistances, Physiol. Mol. Plant Pathol. 47 (1995) 119-140.

[60] Zeyen R.J., Carver T.L.W., Lyngkjær M.F., The Formation and Role of Papillae, in: Belanger R.R., Dik A.J., Bushnell W.R. (Eds.), The Powdery Mildews: A Comprehensive Treatise, APS Press, St. Paul, Minnesota, US, in preparation.

To access this journal online: www.edpsciences.org 